\title{
Quality Characters of Maize and NPK Status of Soil as Influenced by Various Sole and Intercropping Treatments
}

\author{
A.K. Patel", R.B. Ardeshna and Dinesh Kumar \\ Department of Agronomy, N. M. College of Agriculture, Navsari Agricultural University, \\ Navsari - 396 450, Gujarat, India \\ *Corresponding author
}

\section{A B S T R A C T}

\begin{tabular}{|l|}
\hline Key w or d s \\
Green gram, \\
Cowpea, protein, \\
Oil, Total \\
carbohydrate, \\
Nitrogen, \\
Phosphorous, \\
Potash. \\
\hline Article Info \\
\hline $\begin{array}{l}\text { Accepted: } \\
\text { 19 July } 2017 \\
\text { Available Online: } \\
\text { 10 September } 2017\end{array}$ \\
\hline
\end{tabular}

\begin{abstract}
A field experiment was carried out at College Farm, Navsari Agricultural University, Navsari (Gujarat) to study the quality characters and yield potential of summer maize based intercropping systems during summer season of 2016. The experiment was laid out in randomized block design with four replications and ten treatments. Protein, oil and carbohydrates content of maize were not affected significantly by various treatments. Both sole maizetreatments $\left(T_{1}\right.$ and $\left.T_{2}\right)$ were statistically at par with respect to protein, oil and total carbohydrate yield. Intercropping treatments significantly declined protein, oil and total carbohydrate yield of maize except $T_{5}-$ maize + green gram (1:1). The effect of different treatments was significant on available $\mathrm{N}$ and $\mathrm{P}_{2} \mathrm{O}_{5}$ status of soil after crop harvest, but non-significant on available $\mathrm{K}_{2} \mathrm{O}$. Available $\mathrm{N}$ and $\mathrm{P}_{2} \mathrm{O}_{5}$ content after crop harvest in soil were recorded remarkably higher in sole green gram $\left(\mathrm{T}_{3}\right)$ and sole cowpea $\left(\mathrm{T}_{4}\right)$ closely followed by maize + green gram/cowpea intercropping treatments and least in sole maize. Among the intercropping treatments, maize + green gram (Paired 2:2) $\left(\mathrm{T}_{7}\right)$ recorded maximum available $\mathrm{N}$ and $\mathrm{P}_{2} \mathrm{O}_{5}$ content after crop harvest in soil followed by maize + green gram $(1: 1)\left(\mathrm{T}_{5}\right)$.
\end{abstract}

\section{Introduction}

Maize is one of the most important cereal crops of the world and contributes to food security in most of the developing countries. United States is the largest maize producer and also has a large surplus, which also makes it the largest maize exporter. Brazil, Ukraine and Argentina are the other key maize producing countries behind USA. The four countries together account for $80-85 \%$ of the total exports in maize. In India, maize is emerging as third most important crop after rice and wheat. Its importance lies in the fact that it is not only used for human food and animal feed but at the same time it is also widely used for corn starch industry, corn oil production, baby corns etc.

Some of the established and speculated advantages of cereal-legume intercropping systems are higher yields, greater land use efficiency and improvement of soil fertility through nitrogen fixation by component legume (Willey, 1979). In addition, legume intercrops are included in cropping systems because they reduce soil erosion and suppress weeds. Cereal like maize, pearlmillet and sorghum are traditionally intercropped with legumes like green gram, cowpea, black gram 
and groundnut.Such cereal/legume mixtures probably reduce competition for nitrogen, since the legume depends mainly on its own $\mathrm{N}$ fixation while the cereal uses mineral $\mathrm{N}$ (Banik and Sharma, 2009).

\section{Materials and Methods}

An experiment was conducted during summer season of 2016 at College Farm, Navsari Agricultural University, Navsari (Gujarat). The climate of this zone is typically tropical, characterized by humid and warm monsoon with heavy rains, cold winter and fairly hot summer. The average annual rainfall of the tract is about $1500 \mathrm{~mm}$. The summer season commences by the middle of February and the temperature reaches to its maximum in April or May. Thus, April and May are the hottest months of the season/year.

The overall meteorological data (Table 1) revealed that the weather and climate conditions were normal and favorable for the growth and development of maize and pulse crops.

The experimental soil was clayey in texture, slightly alkaline $(\mathrm{pH} 7.8)$ in reaction with normal electric conductivity $(0.65 \mathrm{dS} / \mathrm{m})$, low in available nitrogen $(214 \mathrm{~kg} / \mathrm{ha})$, medium in phosphorous $(35.16 \mathrm{~kg} / \mathrm{ha})$ and rich in potassium $(345.50 \mathrm{~kg} / \mathrm{ha})$.

Total ten treatments viz., $\mathrm{T}_{1^{-}}$sole maize, $\mathrm{T}_{2}$ sole maize (Paired rows at $45-75 \mathrm{~cm}$ ), $\mathrm{T}_{3}-$ sole green gram, $\mathrm{T}_{4}$-sole cowpea, $\mathrm{T}_{5}$ - maize + green gram (1:1), $\mathrm{T}_{6}$-maize + green gram (Paired 2:1), $\mathrm{T}_{7}$-maize + green gram (Paired 2:2), $\mathrm{T}_{8}-$ maize + cowpea $(1: 1), \mathrm{T}_{9}-$ maize + cowpea (Paired 2:1), $\mathrm{T}_{10}$ - maize + cowpea (Paired 2:2) were tried in randomized block design with four replications.

Representative samples of seed were taken from each treatment and dried in oven at $65^{\circ} \mathrm{C}$ temperature for 24 hours and powdered by mechanical grinder. Then the nitrogen content of seed was determined by micro Kjheldahl's method (Jackson, 1967). The protein content in seed was calculated by multiplying nitrogen content of seed (\%) with the conversion factor of 6.25 (Bhuiya and Chowdhary, 1974). The protein yield in seed was calculated by using the following formula.

Protein yield $(\mathrm{kg} / \mathrm{ha})=\frac{\text { Protein content in seed }(\%) \times \text { Seed yield }(\mathrm{kg} / \mathrm{ha})}{100}$

Representative seed samples were taken from each treatment and grind by mortar and pestle. Then oil content of seed was determined by Automatic Soxhlet Extractor. The oil content in seeds is expressed as percentage. The oil yield was computed for each treatment by using the following formula.

Oil yield $(\mathrm{kg} / \mathrm{ha})=\frac{\text { Oil content in seed }(\%) \times \text { Seed yield }(\mathrm{kg} / \mathrm{ha})}{100}$

The total carbohydrate content (\%) was estimated from the grinded grain of maize representative samples using phenol sulphuric acid method (Krishnaveni et al., 1984). The total carbohydrate content yield was computed for each treatment by using the following formula.

Total carbohy drate yield $(\mathrm{kg} / \mathrm{ha})=\frac{\text { Total carbohy drate content in seed }(\%) \times \text { Seed yield }(\mathrm{kg} / \mathrm{ha})}{100}$ 
For estimation of available $\mathrm{N}, \mathrm{P}$ and $\mathrm{K}$ in soil after harvest of crop, respective soil samples were drown from each plot at $30 \mathrm{~cm}$ soil depth and analyzed for determination of content of respective nutrient using the following methods.

The statistical analysis of data recorded for different characters during the course of investigation was carried out through the procedure appropriate to the Randomized Block Design of the experiment as described by Panse and Sukhatme (1967). The significance of difference was tested by ' $F$ ' test. Five per cent level of significance was used to test the significance of results. The critical differences were calculated when the differences among treatments were found significant in ' $\mathrm{F}$ ' test. In the remaining cases, only standard error of means was worked out. The co-efficient of variance (C.V. \%) was also worked out.

\section{Results and Discussion}

\section{Yield and quality}

\section{Grain yield (kg/ha)}

The results (Table 2) indicated significant influence of different treatments on grain yield of maize. Sole maize viz., normal sowing $\left(\mathrm{T}_{1}\right)$ and paired rows at $45-75 \mathrm{~cm}\left(\mathrm{~T}_{2}\right)$ with 3325 and $3176 \mathrm{~kg} / \mathrm{ha}$ grain yield were statistically at par and recorded higher grain yield as compared to all maize + green gram and maize + cowpea intercropping treatments. The maximum reduction in grain yield of maize due to cowpea intercropping can be ascribed to its relatively luxuriant vegetative growth of cowpea as compared to green gram which supress the growth of maize. Similar results of reduction in grain yield of maize under intercropping systems are also in agreement with the findings of Sheoran et al., (2010), Chaudhary et al., (2014), Mandal et al., (2014).
In comparison of intercropping treatments, treatment $\mathrm{T}_{5}-$ maize + green gram $(1: 1)$ recorded the maximum grain yield of maize followed by $\mathrm{T}_{8}-$ maize + cowpea $(1: 1), \mathrm{T}_{7}-$ maize + green gram (Paired 2:2) and $\mathrm{T}_{9}-$ maize + cowpea (Paired 2:2).

\section{Protein content $(\%)$}

Results (Table 2) revealed that there was no significant effect of different treatments on protein content of maize. However, protein content was recorded numerically higher in sole maize $\left(\mathrm{T}_{1}\right)$ closely followed by sole maize (Paired rows at $45-75 \mathrm{~cm}$ ). The higher protein content of maize in sole maize was observed by Mandal et al., (2014).

\section{Protein yield (kg/ha)}

The effect of different treatments was found to be significant on protein yield of maize (Table 2). The maximum protein yield (343.96 kg/ha) was recorded in $\mathrm{T}_{1}-$ sole maize which was statistically at par with $\mathrm{T}_{2}-$ sole maize (Paired rows at 45-75 cm) $(326.66$ $\mathrm{kg} / \mathrm{ha})$ and $\mathrm{T}_{5}-$ maize + green gram (1:1) (302.39 kg/ha).

\section{Oil content (\%)}

The data (Table 2) indicated that there was reduction in oil content of maize under various intercropping treatments, but the differences could not reach to the significant level when compared with sole maize except maize + green gram (1:1).

This might be owing to the fact that oil content is a varietal character and less influenced by environment.

The non-significant effect of legume intercrops on oil content of maize was also reported by Sultana et al., (2013). 


\section{Oil yield (kg/ha)}

The results (Table 2) showed significant influence of different treatments on oil yield of maize. The results revealed that both sole maize treatments viz., $\mathrm{T}_{1}$ - sole maize and $\mathrm{T}_{2}-$ sole maize (Paired rows at $45-75 \mathrm{~cm}$ ) recorded oil yield of 220.17 and $208.21 \mathrm{~kg} / \mathrm{ha}$, respectively and were statistically at par.

Intercropping green gram and cowpea with maize in various row ratios reduced the oil yield of maize as compared to sole maize. Among the intercropping treatments, $\mathrm{T}_{5}-$ maize + green gram (1:1) recorded higher oil yield of maize (191.46 kg/ha).

This significant difference in oil yield might be due to large variation in grain yield of maize under different treatments.

\section{Total carbohydrate content $(\%)$}

Results (Table 2) revealed that there was no significant effect of different treatments on total carbohydrate content of maize. However, total carbohydrate content was recorded numerically higher in sole maize $\left(\mathrm{T}_{1}\right)$ closely followed by sole maize (Paired rows at 45-75 $\mathrm{cm})$.

Estimation of available $N, P$ and $K$ in soil after harvest of crop, respective soil samples were drown from each plot at $30 \mathrm{~cm}$ soil depth and analyzed for determination of content of respective nutrient using the following methods

\begin{tabular}{|c|c|c|c|}
\hline Sr. No. & Particulars & Procedure used & Reference \\
\hline 1. & Available Nitrogen & Alkaline potassium permanganate method & Jackson (1967) \\
\hline 2. & Available Phosphorus & Spectrophotometric method (Olsen's method) & Jackson (1967) \\
\hline 3. & Available Potassium & Flame photometric method & Jackson (1967) \\
\hline
\end{tabular}

Table.1 Mean weekly meteorological data during crop season of the year 2016

\begin{tabular}{|c|c|c|c|c|c|c|c|}
\hline $\begin{array}{c}\text { Month \& } \\
\text { Year }\end{array}$ & $\begin{array}{c}\text { Std. } \\
\text { Week }\end{array}$ & \multirow{2}{*}{ Date } & \multicolumn{2}{c|}{ Temperature $\mathbf{(}^{\mathbf{0}}$ ) } & \multicolumn{2}{c|}{ Relative humidity (\%) } & Sun shine \\
\cline { 4 - 7 } & & Max. & Min. & Max. & Min. & hrs. day \\
\hline \multirow{4}{*}{ Feb. 2016 } & 6 & $01-06$ & 30.3 & 12.9 & 86.7 & 38.0 & 9.9 \\
& 7 & $07-13$ & 29.5 & 13.8 & 85.1 & 35.1 & 7.7 \\
& 8 & $14-20$ & 32.6 & 15.9 & 84.3 & 34.7 & 8.6 \\
& 9 & $21-27$ & 34.3 & 18.6 & 79.5 & 34.9 & 8.6 \\
\hline \multirow{4}{*}{ Mar. 2016 } & 10 & $28-05$ & 33.9 & 17.4 & 88.3 & 27.7 & 8.6 \\
& 11 & $06-12$ & 33.5 & 18.4 & 84.7 & 25.9 & 9.0 \\
& 12 & $13-19$ & 36.3 & 19.0 & 82.5 & 21.1 & 9.1 \\
& 13 & $20-26$ & 38.0 & 19.6 & 87.5 & 29.7 & 8.2 \\
& 14 & $27-02$ & 34.8 & 21.5 & 91.4 & 41.7 & 7.5 \\
\hline \multirow{4}{*}{ April 2016 } & 15 & $03-09$ & 36.9 & 21.0 & 83.0 & 30.6 & 9.4 \\
& 16 & $10-16$ & 36.5 & 22.9 & 84.9 & 39.4 & 9.8 \\
& 17 & $17-23$ & 33.8 & 22.8 & 69.6 & 45.5 & 10.5 \\
& 18 & $24-30$ & 34.9 & 24.1 & 86.7 & 53.2 & 9.3 \\
\hline \multirow{4}{*}{ May 2016 } & 19 & $01-07$ & 33.8 & 25.2 & 86.8 & 59.6 & 9.3 \\
& 20 & $08-14$ & 36.0 & 26.4 & 87.5 & 54.2 & 9.2 \\
& 21 & $15-21$ & 33.5 & 28.4 & 78.5 & 62.7 & 8.6 \\
& 22 & $22-28$ & 34.7 & 28.1 & 74.2 & 60.0 & 9.4 \\
& 23 & $29-31$ & 34.2 & 28.3 & 83.9 & 76.9 & 7.5 \\
\hline
\end{tabular}


Table.2 Protein content (\%), protein yield (kg/ha), oil content, oil yield, total carbohydrate content (\%) and total carbohydrate yield of Maize as influenced by sole and intercropping treatments

\begin{tabular}{|c|c|c|c|c|c|c|c|}
\hline Treatment & $\begin{array}{l}\text { Seed } \\
\text { yield } \\
\text { (kg/ha) }\end{array}$ & $\begin{array}{c}\text { Protein } \\
\text { content } \\
(\%)\end{array}$ & $\begin{array}{l}\text { Protein } \\
\text { yield } \\
\text { (kg/ha) }\end{array}$ & $\begin{array}{c}\text { Oil } \\
\text { content } \\
(\%)\end{array}$ & $\begin{array}{c}\text { Oil yield } \\
\text { (kg/ha) }\end{array}$ & $\begin{array}{c}\text { Total } \\
\text { carbohydrate } \\
\text { content }(\%)\end{array}$ & $\begin{array}{c}\text { Total } \\
\text { carbohydrate } \\
\text { yield (kg/ha) }\end{array}$ \\
\hline Sole maize & 3325 & 10.34 & 343.96 & 6.63 & 220.17 & 74.21 & 2467.24 \\
\hline Sole maize (Paired rows at $45-75 \mathrm{~cm}$ ) & 3176 & 10.28 & 326.66 & 6.55 & 208.21 & 74.14 & 2349.28 \\
\hline Sole green gram & - & - & - & - & - & - & - \\
\hline Sole cowpea & - & - & - & - & - & - & - \\
\hline Maize + green gram $(1: 1)$ & 2962 & 10.21 & 302.39 & 6.46 & 191.46 & 74.01 & 2189.65 \\
\hline Maize + green gram (paired 2:1) & 2655 & 9.94 & 263.51 & 6.06 & 160.64 & 73.58 & 1956.64 \\
\hline Maize + green gram (paired 2:2) & 2790 & 10.06 & 280.36 & 6.28 & 174.52 & 73.80 & 2058.64 \\
\hline Maize + cowpea $(1: 1)$ & 2916 & 10.17 & 296.58 & 6.40 & 186.55 & 73.91 & 2153.70 \\
\hline Maize + cowpea (paired 2:1) & 2618 & 9.87 & 258.74 & 5.98 & 156.31 & 73.47 & 1921.37 \\
\hline Maize + cowpea (paired 2:2) & 2737 & 10.01 & 273.84 & 6.20 & 169.93 & 73.71 & 2020.64 \\
\hline S.Em. \pm & 146 & 0.15 & 15.67 & 0.16 & 10.26 & 1.31 & 105.54 \\
\hline C.D. at $5 \%$ & 431 & N.S. & 46.09 & N.S. & 30.18 & N.S. & 310.41 \\
\hline
\end{tabular}


Table.3 Available $\mathrm{N}, \mathrm{P}_{2} \mathrm{O}_{5}$ and $\mathrm{K}_{2} \mathrm{O}$ status of soil after harvest as influenced by sole and intercropping treatments

\begin{tabular}{|l|c|c|c|}
\hline \multicolumn{1}{|c|}{ Treatment } & $\begin{array}{c}\text { Available N } \\
(\mathbf{k g} / \mathbf{h a})\end{array}$ & $\begin{array}{c}\text { Available } \\
\mathbf{P}_{\mathbf{2}} \mathbf{O}_{\mathbf{5}}(\mathbf{k g} / \mathbf{h a})\end{array}$ & $\begin{array}{c}\text { Available } \\
\mathbf{K}_{\mathbf{2}} \mathbf{O}(\mathbf{k g} / \mathbf{h a})\end{array}$ \\
\hline Sole maize & 189.82 & 30.34 & 319.45 \\
\hline Sole maize (Paired rows at 45-75 cm) & 194.54 & 31.15 & 320.44 \\
\hline Sole green gram & 269.42 & 41.11 & 343.56 \\
\hline Sole cowpea & 261.47 & 39.93 & 342.23 \\
\hline Maize + green gram (1:1) & 238.58 & 37.05 & 336.87 \\
\hline Maize + green gram (paired 2:1) & 220.85 & 36.04 & 325.14 \\
\hline Maize + green gram (paired 2:2) & 242.76 & 37.21 & 339.21 \\
\hline Maize + cowpea (1:1) & 230.79 & 36.25 & 327.15 \\
\hline Maize + cowpea (paired 2:1) & 215.84 & 34.50 & 322.51 \\
\hline Maize + cowpea (paired 2:2) & 236.88 & 36.75 & 329.47 \\
\hline S.Em. \pm & 7.07 & 0.90 & 10.04 \\
\hline
\end{tabular}

\section{Total carbohydrate yield (kg/ha)}

The effect of different treatments was found to be significant on total carbohydrate yield of maize grains (Table 2). The maximum total carbohydrate yield (2467.24 $\mathrm{kg} / \mathrm{ha})$ was recorded in $\mathrm{T}_{1}$ - sole maize which was statistically at par with $\mathrm{T}_{2}-$ sole maize (Paired rows at $45-75 \mathrm{~cm})(2349.28 \mathrm{~kg} / \mathrm{ha})$ and $\mathrm{T}_{5}-$ maize + green gram $(1: 1)(2189.65$ $\mathrm{kg} / \mathrm{ha}$ ).

\section{NPK status of soil (After crop harvest)}

\section{Available $\mathrm{N}$ in soil (kg/ha)}

The results pertaining to the available $\mathrm{N}$ status of soil after crop harvest (Table 3) showed significant differences on available $\mathrm{N}$ in soil due to different treatments.

The maximum available $\mathrm{N}$ status of soil after crop harvest was observed in $\mathrm{T}_{3}$ - sole green gram $(269.42 \mathrm{~kg} / \mathrm{ha})$ followed by $\mathrm{T}_{4}-$ sole cowpea $(261.47 \mathrm{~kg} / \mathrm{ha})$. Both sole maize treatments $\left(T_{1}\right.$ and $\left.T_{2}\right)$ were statistically at par and recorded lower $\mathrm{N}$ status as compared to rest of the treatments. Among the intercropping treatments, $\mathrm{T}_{7}-$ maize + green gram (Paired 2:2) recorded the highest available $\mathrm{N}$ content in soil which was statistically at par with $\mathrm{T}_{5}-$ maize + green gram (1:1), $\mathrm{T}_{10}-$ maize + cowpea (Paired 2:2) and $\mathrm{T}_{8}-$ maize + cowpea $(1: 1)$.

Maximum available $\mathrm{N}$ content in soil after crops harvest in both sole pulses $\left(\mathrm{T}_{3}\right.$ and $\left.\mathrm{T}_{4}\right)$ as well as intercropping treatments might be due to fixation of atmospheric nitrogen by rhizobium bacteria in nodules on their roots and mineralization of $\mathrm{N}$ from organic residues. This could also be ascribed to the residual effect of applied chemical fertilizer to respective crops based on recommendation dose. Same results were also reported by Padhi and Panigrahi (2006), Dahmardeh et al., (2010), Sheoran et al., (2010), Girijesh et al., (2015) and Kaushal et al., (2015).

\section{Available $\mathrm{P}_{2} \mathrm{O}_{5}$ in soil $(\mathrm{kg} / \mathrm{ha})$}

The effect of various treatments on available $\mathrm{P}_{2} \mathrm{O}_{5}$ in soil after crop harvest was found to be significant (Table 3). The differences in available $\mathrm{P}_{2} \mathrm{O}_{5}$ content of soil after crop harvest were non-significant in case of sole maize treatments $\left(T_{1}\right.$ and $\left.T_{2}\right)$. The status was improved to some extent under sole green 
gram and sole cowpea followed by maize + green gram/cowpea intercropping treatments.

Increase in available $\mathrm{P}_{2} \mathrm{O}_{5}$ status in soil due to pulse crops secrete greater amount of acid phosphatases in soil from roots than maize. To increase plant stand of pulses in intercropping, amount of phosphorus was increased. Dahmardeh et al., (2010) and Girijesh et al., (2015) also found maximum available $\mathrm{P}_{2} \mathrm{O}_{5}$ status in soil after crop harvest in sole intercrops (legumes) followed by intercropping treatments compared to sole maize.

\section{Available $\mathrm{K}_{2} \mathrm{O}$ in soil (kg/ha)}

The results indicated non-significant effect of different treatments on available $\mathrm{K}_{2} \mathrm{O}$ content in soil after crop harvest (Table 3). However, available $\mathrm{K}_{2} \mathrm{O}$ content in soil recorded numerically higher in sole green gram $\left(\mathrm{T}_{3}\right)$ closely followed by sole cowpea $\left(\mathrm{T}_{4}\right)$. Intercropping as well as sole maize treatments showed lower available $\mathrm{K}_{2} \mathrm{O}$ content in soil.

Higher available $\mathrm{K}_{2} \mathrm{O}$ content in soil under sole pulses might be due to deep root system of pulses, they could absorb $\mathrm{K}_{2} \mathrm{O}$ from the deep soil level and increased biological and chemical activity in rhizosphere might have resulted in higher available potassium content in soil. Similar results were also reported by Dahmardeh et al., (2010) and Girijesh et al., (2015).

\section{References}

Banik, P., and Sharma, R. C. 2009. Yield and resource utilization efficiency in baby corn-legume-intercropping system in the eastern plateau of India. Journal of Sustainable Agriculture, 33(4): 379395.

Bhuiya, Z.H., and Chowdhary S V. 1974. Effect of $\mathrm{N}, \mathrm{P}, \mathrm{K}$ and $\mathrm{S}$, on quality of groundnut. Indian Journal of Agricultural Science, 44(1): 751-754.

Choudhary, V.K., Dixit, A., Sureshkumar, P. and Chauhan, B.S. (2014). Productivity, weed dynamics, nutrient mining and monetary advantage of maize-legume intercropping in the eastern Himalaya region of India. Plant Production Science, 17(4): 342-352.

Dahmardeh, M., Ghanbari, A., Syahsar, B. A. and Ramrodi, M. (2010).The role of intercropping maize (Zea mays L.) and cowpea (Vigna unguiculata L.) on yield and soil chemical properties. African Journal of Agricultural Research, 5(8): 631-636.

Girijesh, G.K., Kumaraswamy A S and Nataraju S P. 2015. Studies on changes in soil fertility, maize equivalent yield and nutrient recycling in different maize (Zea mays L.) based intercropping systems. Karnataka Journal of Agricultural Sciiences, 28(2): 147-150.

Jackson, M.L., 1967. "Soil Chemical Analysis". Prentice Hall of India Private Limited, New Delhi, pp. 183-192.

Kaushal, S., Rameshwar; Saini, J. P., Punam and Sankhyan, N. K. (2015).Performance of maize (Zea mays)-based intercropping systems and their residual effect on wheat (Triticum aestivum) + lentil (Lens culinaris) intercropping system under organic conditions. Indian Journal of Agronomy, 60(2): 224-229.

Krishnaveni, S., Balasubramaniyan, $\mathrm{T}$ and Sadasivam, S. (1984). Food Chemistry, 15: (229).

Mandal, M. K., Banerjee, M. and Banerjee, H. (2014). Evaluation of maize (Zea mays) - legume intercropping system under red and lateritic tract of West Bengal. SAARC Journal of Agriculture, 12(1): 117-126.

Padhi, A.K., and Panigrahi R K. 2006. Effect of intercrop and crop geometry on 
productivity, economics, energetics and soil-fertility status of maize (Zea mays)based intercropping systems. Indian Journal of Agronomy, 51(3): 174-177.

Panse, V.G., and Sukhatme P V 1967. "Statistical Methods for Agricultural Workers". ICAR, New Delhi.

Sheoran, P., Sardana, V., Singh, S. and Bhushan, B. (2010). Bio-economic evaluation of rainfed maize (Zea mays)based intercropping systems with blackgram (Vignamungo) under different spatial arrangements. Indian
Journal of Agricultural Science, 80(3): 244-247.

Sultana, S. R., Tariq, M., Ahmad, A. and Naseem, W. (2013).Productivity of some maize based intercropping systems under different planting geometries. Thai Journal of Agricultural Science, 46(2): 65-70.

Willey, R. W., 1979. Intercropping - its importance and research needs. Part-I. Competition and yield advantages. Field Crop Abstract, 32(1): 1-10.

\section{How to cite this article:}

Patel, A.K., R.B. Ardeshna and Dinesh Kumar. 2017. Quality Characters of Maize and NPK Status of Soil as Influenced by Various Sole and Intercropping Treatments. Int.J.Curr.Microbiol.App.Sci. 6(9): 1558-1565. doi: https://doi.org/10.20546/ijcmas.2017.609.191 